\title{
Mildly elevated blood pressure is a marker for better health status in Polish centenarians
}

\author{
Jan Szewieczek • Jan Dulawa • Tomasz Francuz • Katarzyna Legierska • \\ Beata Hornik • Iwona Włodarczyk-Sporek • Magdalena Janusz-Jenczeń • \\ Agnieszka Batko-Szwaczka
}

Received: 20 June 2014 / Accepted: 4 December 2014 / Published online: 23 December 2014

(C) The Author(s) 2015. This article is published with open access at Springerlink.com

\begin{abstract}
The number of centenarians is projected to rise rapidly. However, knowledge of evidence-based health care in this group is still poor. Hypertension is the most common condition that leads to multiple organ complications, disability, and premature death. No guidelines for the management of high blood pressure (BP) in centenarians are available. We have performed a cross-sectional study to characterize clinical and functional state of Polish centenarians, with a special focus on BP. The study comprised 86 consecutive $100.9 \pm$ 1.2 years old (mean $\pm \mathrm{SD}$ ) subjects (70 women and 16 men). The assessment included structured interview, physical examination, geriatric functional assessment, resting electrocardiography, and blood and urine sampling. The subjects were followed-up on the phone. Subjects who survived 180 days $(83 \%)$ as compared to non-survivors had higher systolic BP (SBP), diastolic
\end{abstract}

J. Szewieczek $(\bowtie) \cdot$ A. Batko-Szwaczka

Department of Geriatrics, School of Health Sciences in

Katowice, SUM, Katowice, Poland

e-mail: jszewieczek@sum.edu.pl

J. Dulawa $\cdot$ K. Legierska

Department of Internal Medicine and Metabolic Diseases, School of Health Sciences in Katowice, SUM, Katowice, Poland

B. Hornik · I. Włodarczyk-Sporek • M. Janusz-Jenczeń Department of Internal Nursing, School of Health Sciences in Katowice, SUM, Katowice, Poland

T. Francuz

Department of Biochemistry, School of Medicine in Katowice, SUM, Katowice, Poland
BP (DPB), mean arterial pressure (MAP), pulse pressure (PP), higher mini-mental state examination, Barthel Index of Activities of Daily Living and Lawton Instrumental Activities of Daily Living Scale scores, higher serum albumin and calcium levels, and total ironbinding capacity, while lower serum creatinine, cystatin $\mathrm{C}$, folate, and C-reactive protein levels. SBP $\geq 140 \mathrm{~mm}$ $\mathrm{Hg}, \mathrm{DBP} \geq 90 \mathrm{~mm} \mathrm{Hg}, \mathrm{MAP} \geq 100 \mathrm{~mm} \mathrm{Hg}$, and PP $\geq 40 \mathrm{~mm} \mathrm{Hg}$ were associated with higher 180-day survival probability. Results suggest that mildly elevated blood pressure is a marker for better health status in Polish centenarians.

Keywords Centenarians $\cdot$ Blood pressure $\cdot$ Cognitive performance Physical performance

\section{Background}

The number of oldest-old people, including centenarians, is projected to rise rapidly over the next decades (Kinsella and He 2009). However, knowledge of evidence-based health care in this group is still poor. Hypertension is the most common condition seen in primary care that leads to multiple organ complications, disability, and premature death (James et al. 2014). Guidelines for the management of high blood pressure (BP) in adults define thresholds for pharmacologic treatment with regard to age over 60 and over 80 years (Mancia et al. 2013; James et al. 2014). No guidelines are available for centenarians. Quality of life and a level of independence in activities of daily living rather than 
life expectancy are matters of the utmost importance at this age. We have performed a cross-sectional study to characterize clinical and functional state of centenarians in Upper Silesia, the most industrialized region of Poland with a special focus on BP. Our preliminary results (Szewieczek et al. 2011) were consistent with those indicating that higher BP was associated with better mental and physical performance in oldest-old people (Nilsson et al. 2007; Euser et al. 2009; Richmond et al. 2011). The paper presents our final results.

\section{Methods}

Participants

The study was carried out from January 2007 through August 2013. The data regarding hundred-year-old inhabitants of the Voivodeship were obtained from the Silesian Voivodeship Administration Office in Katowice, Poland. According to these data, there were 389 centenarians living in 2006 in the province, accounting for $0.008 \%$ of the total population of the area. Eight percent of addressees responded positively to invitation letters. A visit from the team including a physician and two nurses at the place of residence was scheduled both with the subject and their carer. The study comprised 86 consecutive $100.9 \pm 1.2$ years old (mean $\pm \mathrm{SD}$ ) subjects (70 women and 16 men).

\section{Measurements}

The assessment included structured interview, physical examination, geriatric functional assessment, resting electrocardiography, and blood and urine sampling. Resting BP was measured at both arms according to the standard protocol. If there was a difference between the arms, the higher value was taken for further analysis. Mean arterial pressure (MAP) was calculated as a sum of diastolic BP (DBP) and 1/3 of the difference between systolic BP (SBP) and DBP. Pulse pressure (PP) was calculated as a difference between SBP and DBP. Ankle-brachial index (ABI) was calculated according to the recommendations of the American Heart Association, with $\mathrm{ABI}<0.9$ indicating lower extremity peripheral arterial disease (Hirsch et al. 2006). Romhilt-Estes electrocardiographic criteria were used to assess left ventricular hypertrophy (Buxton et al. 2006). Mini- mental state examination (MMSE) was used to assess global cognitive performance (Folstein et al. 1975). Katz Index of Independence in Activities of Daily Living (ADL) (Katz et al. 1963), Barthel Index of Activities of Daily Living (Barthel Index) (Mahoney and Barthel 1965) and Lawton Instrumental Activities of Daily Living Scale (IADL) (Lawton and Brody 1969) were used to assess functional status. MMSE was scored from 0 to 30, ADL - from 0 to 6, Barthel Index - from 0 to 100 , and IADL - from 9 to 27, with higher scores indicating better functional state.

The following laboratory tests were performed: a complete blood count (erythrocyte count, hemoglobin, leukocytes with differential blood count, platelet count), serum levels of albumin, glucose, insulin, bilirubin, creatinine, folate, vitamin $\mathrm{B}_{12}$, cystatin $\mathrm{C}$, total cholesterol, $\mathrm{LDL}$ cholesterol, HDL cholesterol, triglyceride, thyrotropin, Creactive protein, and serum alanine aminotransferase activity. Serum levels of sodium, potassium, calcium, phosphorus (inorganic), iron, and total iron-binding capacity were measured only in 49 subjects. CKD-EPI creatininecystatin C equation (Inker et al. 2012) and BIS_creatininecystatin $\mathrm{C}$ equation (Schaeffner et al. 2012) were used to estimate glomerular filtration rate (eGFR). The methods are recommended in very elderly persons (Lopes et al. 2013). Insulin resistance was calculated according to the Homeostasis Model Assessment (HOMA ${ }_{I R}$ ) formula (Matthews et al. 1985).

The study subjects were followed up on the phone for at least 180 days after the examination.

Two subjects refused their consent for blood sampling.

\section{Statistical analysis}

The obtained data were analyzed using STATISTICA software version 10 (StatSoft, Inc., USA; StatSoft Poland). Linear and nonlinear regression models were used to assess relationships between selected variables. The Kaplan-Meier method was used to estimate survival probability in subgroups of centenarians distinguished on the basis of different values of the analyzed variables, while differences between these subgroups were assessed with the Wilcoxon-Gehan statistic. The nonparametric Spearman's rank correlation coefficient was used to assess relationships between functional measures and variables analyzed in the study. Nonparametric Mann-Whitney $U$ test was used to compare the data between 180-day survivors and non-survivors. $P<0.05$ was considered statistically significant. 
Ethics

The study protocol was approved by the Bioethical Committee of the Medical University of Silesia. Written informed consent was obtained from each subject and/or their carer after the aim of the study; protocol and risks were explained.

\section{Results}

The most common symptoms reported by the subjects or their carers were as follows: memory disorders (79\%), pain (78\%), and falls (77\%). The most frequent reported diseases were as follows: dementia (73\%), heart failure $(65 \%)$, and osteoarthritis $(64 \%)$. The majority of subjects $(89 \%)$ never smoked. Sixty-three percent of subjects used at least one antihypertensive drug. Characteristics of the group are presented in Table 1 . SBP $\geq 140 \mathrm{~mm} \mathrm{Hg}$ was found in $69.8 \%$, and $\mathrm{DBP} \geq 90 \mathrm{~mm} \mathrm{Hg}$ in $27.9 \%$ of subjects. $\mathrm{ABI} \leq 0.9$ was found in $37.5 \%$ of subjects. Seventy-one subjects (83\%) survived 180 days or more. Survivors as compared to non-survivors had higher SBP and MAP values, higher MMSE, ADL, Barthel Index and IADL scores, higher serum level of albumin and calcium, and higher total iron-binding capacity, and lower serum levels of creatinine, cistatin $\mathrm{C}$, folate, and C-reactive protein (Table 1). No significant differences between survivors and non-survivors in blood count, serum levels of glucose, insulin, bilirubin, vitamin $\mathrm{B}_{12}$, total cholesterol, LDL cholesterol, HDL cholesterol, triglyceride, thyrotropin, sodium, potassium, phosphorus (inorganic) and iron, as well as in serum alanine aminotransferase activity, eGFR, ABI or Romhilt-Estes ECG scores were found. Individuals with SBP $\geq 140 \mathrm{~mm} \mathrm{Hg}$ had higher 180-day survival probability $(p=0.007)$, similar to those with DBP $\geq 90 \mathrm{~mm} \mathrm{Hg}(p=0.046)$, MAP $\geq 100 \mathrm{~mm} \mathrm{Hg}(p=0.011)$, and $\mathrm{PP} \geq 40 \mathrm{~mm} \mathrm{Hg}(p<0.001)$ (Fig. 1). SBP $\geq 145 \mathrm{~mm} \mathrm{Hg}$ was still associated with higher 180 -day survival probability $(p=0.042)$, while $\mathrm{SBP} \geq 150 \mathrm{~mm} \mathrm{Hg}$ was not associated with significantly

Table 1 Clinical and functional characteristics of the whole group, 180-day survivors and non-survivors

\begin{tabular}{|c|c|c|c|c|}
\hline & $\begin{array}{l}\text { All subjects } \\
n=86\end{array}$ & $\begin{array}{l}\text { Survivors }^{\mathrm{a}} \\
n=71\end{array}$ & $\begin{array}{l}\text { Non-survivors } \\
n=15\end{array}$ & $\begin{array}{l}\text { Survivors vs. } \\
\text { non-survivors }\end{array}$ \\
\hline Variable & Mean & & & $p$ \\
\hline Body mass index, $\mathrm{kg} / \mathrm{m}^{2}$ & $23.7 \pm 4.4$ & $23.8 \pm 4.7$ & $23.5 \pm 3.2$ & 0.991 \\
\hline Systolic blood pressure, $\mathrm{mm} \mathrm{Hg}$ & $150.0 \pm 28.2$ & $153.2 \pm 28.4$ & $134.0 \pm 22.5$ & 0.015 \\
\hline Diastolic blood pressure, $\mathrm{mm} \mathrm{Hg}$ & $77.3 \pm 14.6$ & $78.3 \pm 15.3$ & $72.7 \pm 10.2$ & 0.123 \\
\hline Mean arterial pressure, $\mathrm{mm} \mathrm{Hg}$ & $101.5 \pm 16.5$ & $103.3 \pm 17.0$ & $93.1 \pm 11.2$ & 0.019 \\
\hline Pulse pressure, $\mathrm{mm} \mathrm{Hg}$ & $72.2 \pm 25.2$ & $74.6 \pm 25.1$ & $60.7 \pm 23.4$ & 0.080 \\
\hline MMSE score & $16.2 \pm 8.1$ & $17.8 \pm 7.2$ & $8.4 \pm 7.7$ & $<0.001$ \\
\hline Katz ADL & $3.21 \pm 2.16$ & $3.61 \pm 2.02$ & $1.33 \pm 1.84$ & $<0.001$ \\
\hline Barthel Index & $57.8 \pm 31.9$ & $63.9 \pm 28.4$ & $29.3 \pm 33.1$ & $<0.001$ \\
\hline Lawton IADL & $11.7 \pm 4.1$ & $12.2 \pm 4.0$ & $9.3 \pm 3.5$ & 0.002 \\
\hline Albumin, $\mathrm{g} / \mathrm{l}$ & $37.5 \pm 5.5$ & $38.3 \pm 5.1$ & $33.5 \pm 5.5$ & 0.005 \\
\hline Creatinine, $\mu \mathrm{mol} / \mathrm{l}$ & $109.1 \pm 104.8$ & $100.9 \pm 26.2$ & $150.0 \pm 253.5$ & 0.044 \\
\hline Cystatin C, ng/ml & $1408.5 \pm 776.9$ & $1307.6 \pm 780.0$ & $1786.7 \pm 680.5$ & 0.040 \\
\hline Folate, $\mathrm{nmol} / 1$ & $14.6 \pm 9.3$ & $13.5 \pm 8.7$ & $19.7 \pm 10.8$ & 0.048 \\
\hline C-reactive protein, $\mathrm{mg} / \mathrm{l}$ & $12.1 \pm 27.5$ & $8.2 \pm 11.4$ & $31.3 \pm 60.0$ & 0.017 \\
\hline Total iron binding capacity, $\mu \mathrm{mol} / 1$ & $51.4 \pm 12.8$ & $53.4 \pm 10.1$ & $39.8 \pm 20.3$ & 0.047 \\
\hline Calcium, mmol/1 & $2.26 \pm 0.14$ & $2.27 \pm 0.15$ & $2.20 \pm 0.08$ & 0.034 \\
\hline CKD-Epi_creatinine-cystatin C equation, $\mathrm{ml} / \mathrm{min} / 1.73 \mathrm{~m}^{2}$ & $42.7 \pm 17.9$ & $43.3 \pm 18.6$ & $39.8 \pm 14.2$ & 0.696 \\
\hline BIS_creatinine-cystatin $\mathrm{C}$ equation, $\mathrm{ml} / \mathrm{min} / 1.73 \mathrm{~m}^{2}$ & $39.0 \pm 17.1$ & $39.7 \pm 18.2$ & $35.8 \pm 10.2$ & 0.602 \\
\hline
\end{tabular}

${ }^{a}$ Biochemical assays were done in 84 subjects, among them were 70 survivors and 14 non-survivors; serum levels of sodium, potassium, calcium, phosphorus (inorganic), iron, and total iron-binding capacity were measured in 49 subjects, among them were 42 survivors and 7 non-survivors 

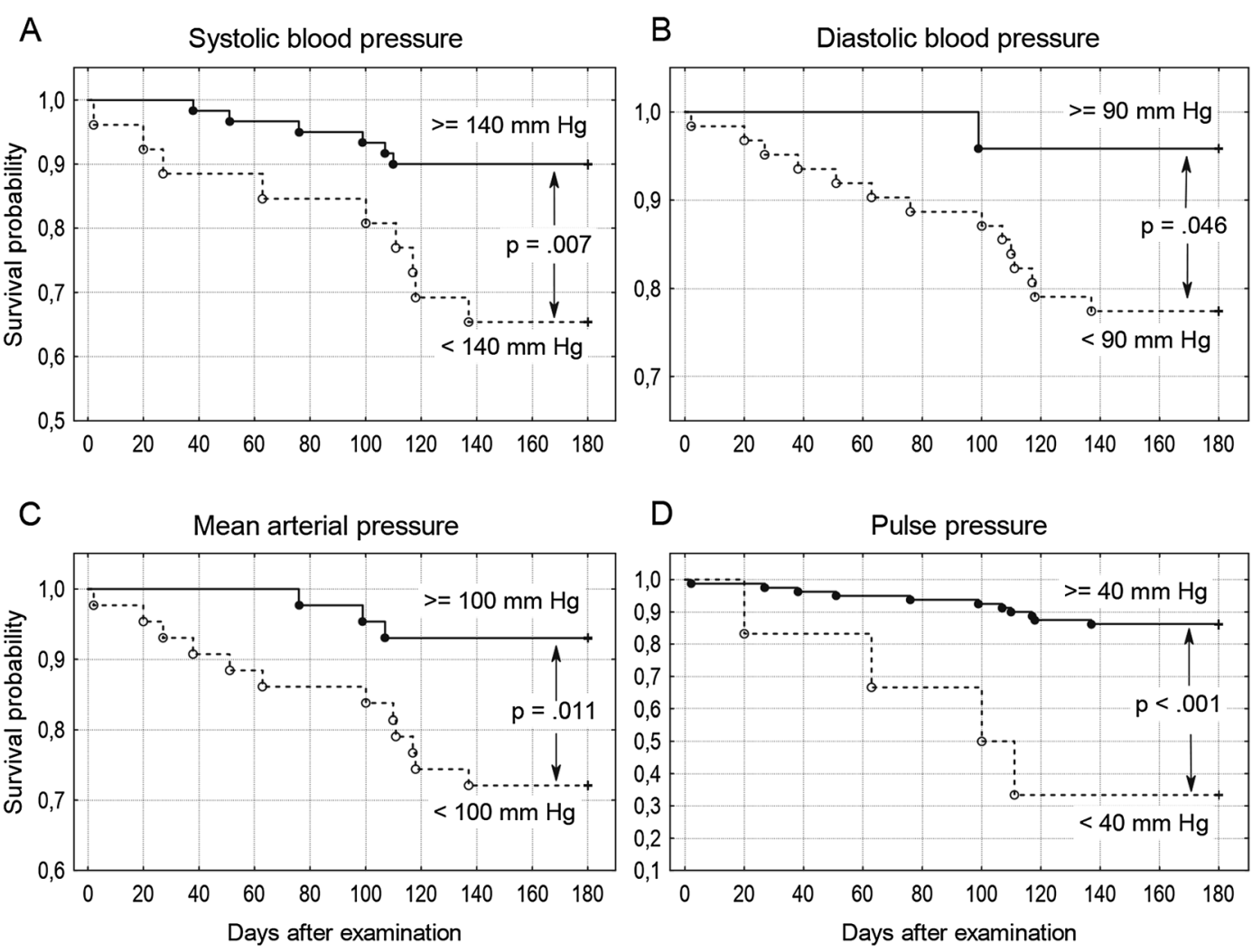

Fig. 1 Individuals with $\mathrm{SBP} \geq 140 \mathrm{~mm} \mathrm{Hg}$ had higher 180-day survival probability $(p=0.007)$, similar to those with $\mathrm{DBP} \geq 90 \mathrm{~mm}$ $\mathrm{Hg}(p=0.046), \mathrm{MAP} \geq 100 \mathrm{~mm} \mathrm{Hg}(p=0.011)$, and $\mathrm{PP} \geq 40 \mathrm{~mm} \mathrm{Hg}$

$(p<0.001)$. a Systolic blood pressure. b Diastolic blood pressure. c Mean arterial pressure. $\mathbf{d}$ Pulse pressure

higher 180 -day survival probability $(p=0.068$ ). InvertedU-shaped relationships, according to the second-degree polynomial pattern between MMSE score and SBP, Barthel Index and SBP, MMSE score and MAP, as well as Barthel Index and MAP were revealed (Fig. 2). Up to the level of around $180 \mathrm{~mm} \mathrm{Hg}$, an increase in SBP was associated with an increase in Barthel Index and MMSE score. Similarly, up to the level of $120 \mathrm{~mm} \mathrm{Hg}$, an increase in MAP was associated with an increase in Barthel Index and MMSE score. Similarly, seconddegree polynomial relationships between MMSE and PP, as well as between Barthel Index and PP were found. Linear correlation (first-degree polynomial approximation) was the best adjusted model to describe the relationship between MMSE score and DBP, as well as between Barthel Index and DBP (Fig. 3). The Spearman's rank correlation coefficient revealed a relationship between functional measures (Barthel Index, IADL and MMSE), blood pressure, and albumin level in centenarians (Table 2).

\section{Discussion}

Hypertension is one of the most common medical conditions leading to multiple cardiovascular complications, disability, and premature death (James et al. 2014). However, substantial differences in the prevalence of hypertension across European countries are observed, from 30 to $45 \%$ of the general population, with a steep increase with aging (Mancia et al. 2013). According to the NATPOL 2011 study, $32 \%$ of adult people in Poland have hypertension (Zdrojewski 2011). PolSenior study revealed that hypertension affects $73.1 \%$ people at the age of $65-69$ years, $74.1 \%$ at the age of $85-89$ years, and $74.6 \%$ of people at the age of $\geq 90$ years in Poland (Zdrojewski et al. 2012). In our study, the assessment was performed by medical staff at the subject's place of residence. Some doubts could arise about categorization of such BP measurement. Home BP monitoring refers to BP measurement "away from the medical environment" (Mancia et al. 

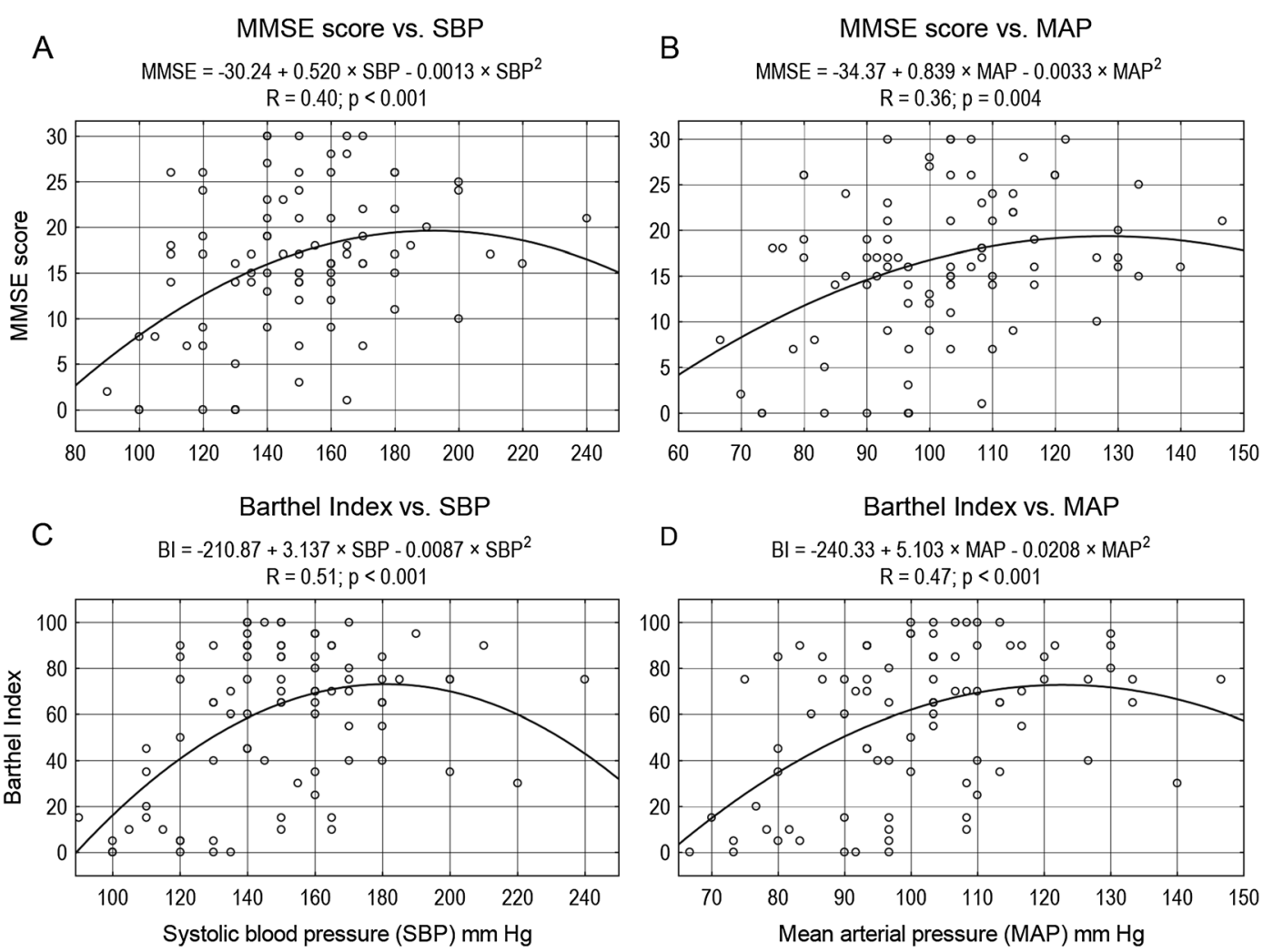

Fig. 2 Inverted-U-shaped relationships, according to the seconddegree polynomial pattern between MMSE score and SBP, Barthel Index and SBP, MMSE score and MAP, as well as Barthel Index

and MAP were revealed. a MMSE score vs. SBP. b MMSE score vs. MAP. c Barthel Index vs. SBP. d Barthel Index vs. MAP

2013) rather than to BP measurement "at home". Therefore, we have assumed that BP measurement performed by a doctor at the patient's place of residence can be considered an equivalent of office BP measurement.

A recent meta-analysis demonstrated that reducing BP to a level of $150 / 80 \mathrm{~mm} \mathrm{Hg}$ is associated with large benefit in stroke, cardiovascular and all-cause mortality, as well as heart failure risk in elderly individuals (the mean age of patients on treatment was 71.04 years) (Briasoulis et al. 2014). Many longitudinal and crosssectional studies demonstrated negative correlation between BP and cognitive performance in middle-aged, young-old, and even old-old individuals (Harrington et al. 2000; Kuo et al. 2005; Knecht et al. 2008; Gamaldo et al. 2008). However, other studies indicated positive correlation between BP and mental or physical performance (reverse epidemiology) in the oldest-old (Nilsson et al. 2007; Molander et al. 2010; Richmond et al. 2011; Sabayan et al. 2012). Waldstein as well as Molander and coworkers found nonlinear relation between SBP and cognitive function with both low and high pressure values associated with poorer results (Waldstein et al. 2005; Molander et al. 2010). Richmond and coworkers found a positive correlation between BP (SBP and DBP) and MMSE scores as well as between BP (SBP and PP) and better functioning on Katz ADL in centenarians (Richmond et al. 2011). Also, our preliminary observations indicated that BP was associated with functional status in a nonlinear fashion with mildly elevated BP (as compared with normal BP defined by threshold values of hypertension (Mancia et al. 2013)) associated with better mental and physical status in Polish centenarians (Szewieczek et al. 2011). Our current analysis confirmed the observations. We have analyzed relationships between functional and clinical measures, as well as between these measures and 180-day survival (Table 1). Measures of mental and physical functional level (MMSE, Katz ADL, Barthel, and Lawton Indexes) appeared to show prognostic factors for survival. On the other hand, they correlated positively to some 

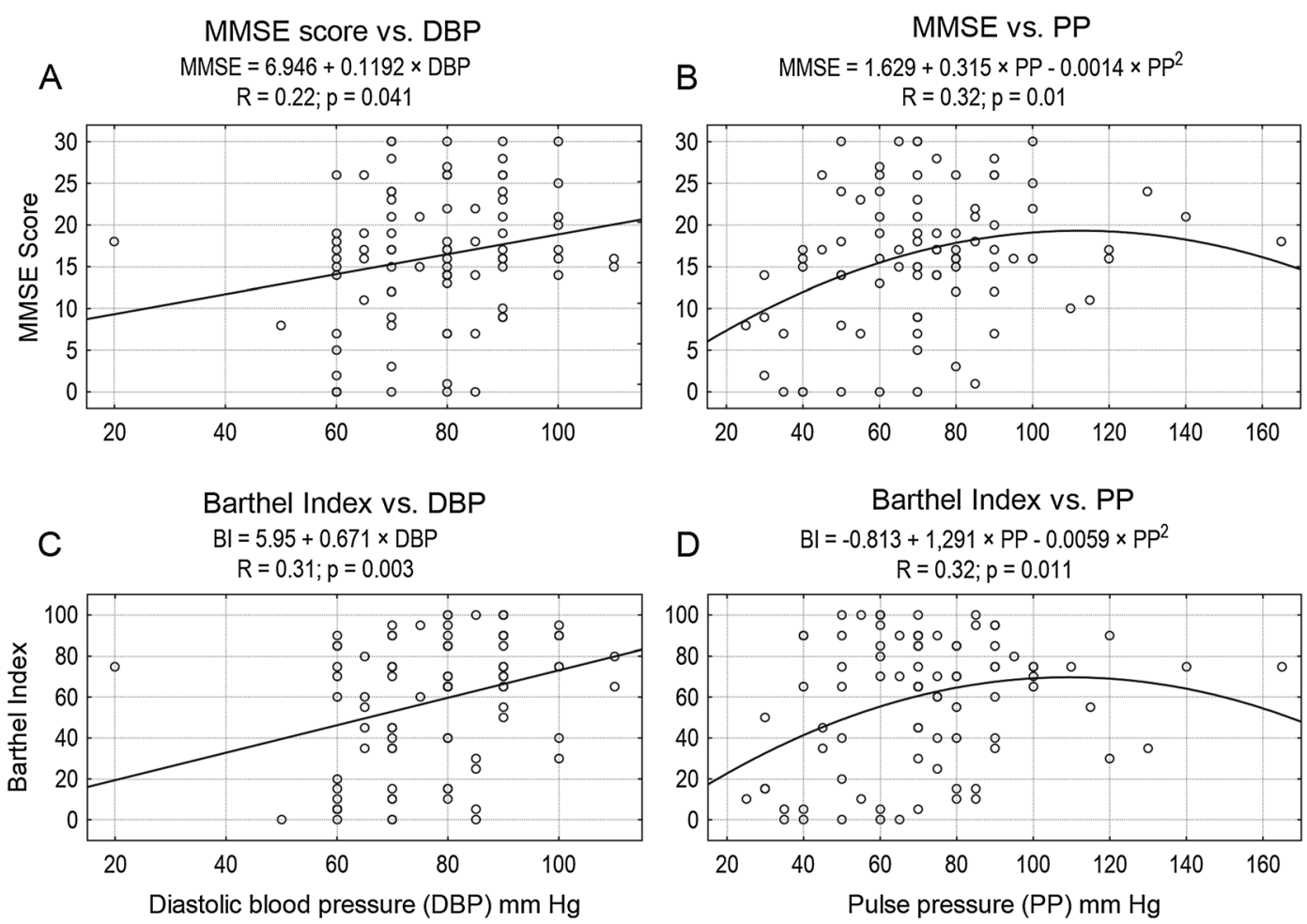

Fig. 3 Linear correlation (first-degree polynomial approximation) was the best adjusted model to describe the relationship between MMSE score and DBP, as well as between Barthel Index and DBP, while inverted-U-shaped relationships (second-degree polynomial

pattern) between MMSE score and PP as well as Barhel Index and PP were revealed. a MMSE score vs. DBP. b MMSE score vs. PP. c Barthel Index vs. DBP. d Barthel Index vs. PP

Table 2 Factors correlated with functional capacity measured using the Barthel Index, Lawton Instrumental Activities of Daily Living Scale (IADL), and MiniMental State Examination (MMSE) in centenarians

\begin{tabular}{lllr}
\hline Functional measure & Correlating factors & $\begin{array}{l}\text { Spearman's rank } \\
\text { correlation coefficient }\end{array}$ & $p$ value \\
\hline Barthel Index & IADL & 0.696 & $<0.000$ \\
& MMSE score & 0.585 & 0.000 \\
& Systolic blood pressure & 0.337 & 0.002 \\
Diastolic blood pressure & 0.339 & 0.001 \\
Mean arterial pressure & 0.379 & $<0.000$ \\
Barthel Index & 0.696 & $<0.000$ \\
MMSE score & 0.658 & $<0.000$ \\
& Systolic blood pressure & 0.350 & 0.001 \\
Diastolic blood pressure & 0.308 & 0.004 \\
Mean arterial pressure & 0.381 & $<0.000$ \\
& Pulse pressure & 0.226 & 0.037 \\
Barthel Index & 0.585 & $<0.000$ \\
IADL & 0.658 & $<0.000$ \\
Systolic blood pressure & 0.327 & 0.002 \\
Diastolic blood pressure & 0.213 & 0.049 \\
Mean arterial pressure & 0.292 & 0.006 \\
& Pulse pressure & 0.257 & 0.017 \\
Albumin level & 0.517 & $<0.000$ \\
\hline & & &
\end{tabular}


degree with BP. However, these functional measures were not independent factors associated with BP (Table 2). A recent study on another group of Polish centenarians also revealed that cognitive and functional performances are predictors of survival. In a group of 340 subjects aged 101.4 \pm 1.4 years, the mean SBP was $140.7 \pm 23.0$ and mean DBP $76.4 \pm 12.6 \mathrm{~mm} \mathrm{Hg}$. PP, SBP, and MAP correlated positively with MMSE, ADL, and IADL score. A higher mean systolic blood pressure and a higher mean pulse pressure were also associated with longer survival, but these associations did not reach the level of significance (Mossakowska et al. 2014). In the Georgia Centenarian Study, the mean SBP and DBP in white centenarians $(126.82 \pm 14.54$ and $72.95 \pm 8.99 \mathrm{~mm}$ $\mathrm{Hg}$, respectively) were lower than in our group. Hypertension was present in $41 \%$ of those subjects, while mean MMSE (17.4 \pm 8.4$)$ was comparable to our group. Data on the association between blood pressure and functional measures are not presented, but facility residents had both lower SBP and lower MMSE (Davey et al. 2010). According to our observations, mildly elevated BP appeared to be a marker of better health (both mental and physical) in the oldest-old, in line with the assumption of Molander and coworkers (Molander et al. 2010). The reason for the association between elevated BP and better functional status in this oldestold cohort is complex. Firstly, decreasing BP can be a symptom of devastating chronic conditions like Alzheimer's and vascular dementia (Guo et al. 1998; Qiu et al. 2004) or heart failure (McKee et al. 1971; Poortvliet et al. 2013), especially in individuals with a history of hypertension (Nilsson et al. 2007; Molander et al. 2010: Taylor et al. 2013). Secondly, elevated BP improves organ perfusion (especially in the brain) that worsens with age as a consequence of progressing age- and disease-related vascular changes (Wang et al. 2010). Adequate perfusion is not only critical for concurrent brain function; hypoperfusion can accelerate neural tissue damage (Molander et al. 2010). Thus, mildly elevated BP seems to be beneficial for both mental and physical function in these oldest-old individuals. However, a problem still exists, as hypertension is a risk factor for devastating, potentially fatal cardiovascular events (James et al. 2014). However, our observations indicate that $\mathrm{SBP}=\geq 140 \mathrm{~mm} \mathrm{Hg}, \mathrm{DBP} \geq 90 \mathrm{~mm}$
$\mathrm{Hg}, \mathrm{MAP} \geq 100 \mathrm{~mm} \mathrm{Hg}$, or $\mathrm{PP} \geq 40 \mathrm{~mm} \mathrm{Hg}$ are associated with higher probability of 180-day survival in Polish centenarians. The findings are consistent with results of studies which demonstrated that SBP lower than $140 \mathrm{~mm} \mathrm{Hg}$ in individuals aged 85-plus or SBP lower than $150 \mathrm{~mm} \mathrm{Hg}$ in nonagenarians is associated with increased mortality (Rastas et al. 2006: Poortvliet et al. 2013). Thus, it may be reasonable to reduce SBP to $150 \mathrm{~mm}$ $\mathrm{Hg}$ (Mancia et al. 2013; James et al. 2014), but "lower is not always better" in the oldest-old.

Limitations of the presented study encompass low inclusion rate of candidates, causing the observation to be extended in time, a relatively small study group, single BP measurement, and incomplete number of laboratory tests. Telephonedocumented 180-day survival defined the life span, whereas the progression of mental and functional disability associated with BP measurements in the surviving centenarians could not be determined due to the lack of the control assessment. Most of the difficulties resulted from the nature of this centenarian cohort. Nevertheless, the observation demonstrated that functional status has higher prognostic value for 180-day survival than any clinical measures, and BP at the level considered as mild hypertension is associated both with better functional status and higher short-term survival probability in Polish centenarians. As it was discussed in our previous paper (Szewieczek et al. 2011), local groups of centenarians can substantially differ. Thus, our conclusion may not necessarily have universal range. BP measurement remains a fundamental method of the medical assessment in centenarians. The question to be solved in further studies is the timepoint when the pharmacological treatment of elevated BP in the oldest-old patients is beneficial.

\section{Conclusion}

Mildly elevated blood pressure is a marker for better health status in Polish centenarians.

Acknowledgments The study was funded by the Medical University of Silesia, Katowice, Poland (grants NN-2-268/06, KNW2-045/08, KNW-2-022/09) and by the National Science Centre, Poland (grant N 404535439 ) from the budget for science in years 2010-2014. 
Conflict of interest The funding body played no role in the formulation of the design, methods, subject recruitment, data collection, analysis, or preparation of this paper.

Open Access This article is distributed under the terms of the Creative Commons Attribution License which permits any use, distribution, and reproduction in any medium, provided the original author(s) and the source are credited.

\section{References}

Briasoulis A, Agarwal V, Tousoulis D, Stefanadis C (2014) Effects of antihypertensive treatment in patients over 65 years of age: a meta-analysis of randomised controlled studies. Heart 100: 317-323

Buxton AE, Calkins H, Callans DJ, DiMarco JP, Fisher JD, Greene HL, Haines DE, Hayes DL, Heidenreich PA, Miller JM et al (2006) ACC/AHA/HRS 2006 Key data elements and definitions for electrophysiological studies and procedures. Circulation 114:2534-2570

Davey A, Elias MF, Siegler IC, Lele U, Martin P, Johnson MA, Hausman DB, Poon LW (2010) Cognitive function, physical performance, health, and disease: norms from the Georgia Centenarian Study. Exp Aging Res 36:394-425

Euser SM, van Bemmel T, Schram MT, Gussekloo J, Hofman A, Westendorp RG, Breteler MM (2009) The effect of age on the association between blood pressure and cognitive function later in life. J Am Geriatr Soc 57:1232-1237

Folstein MF, Folstein SE, McHugh PR (1975) Mini-mental state: a practical method for grading the cognitive state of patients for the clinician. J Psychiatr Res 12:189-198

Gamaldo AA, Weatherbee SR, Allaire JC (2008) Exploring the within-person coupling of blood pressure and cognition in elders. J Gerontol B Psychol Sci Soc Sci 63:P386-P389

Guo Z, Viitanen M, Fratiglioni L, Winbland B (1998) Low blood pressure and early death of elderly people with dementia. Lancet 352:1035-1036

Harrington F, Saxby BK, McKeith IG, Wesnes K, Ford GA (2000) Cognitive performance in hypertensive and normotensive older subjects. Hypertension 36:1079-1082

Hirsch AT, Haskal ZJ, Hertzer NR, Bakal CW, Creager MA, Halperin JL, Hiratzka LF, Murphy WR, Olin JW, Puschett JB et al (2006) ACC/AHA 2005 practice guidelines for the management of patients with peripheral arterial disease (lower extremity, renal, mesenteric, and abdominal aortic). Circulation 113:e463-e465

Inker LA, Schmid CH, Tighiouart H, Eckfeldt JH, Feldman HI, Greene T, Kusek JW, Manzi J, Van Lente F, Zhang YL et al (2012) Estimating glomerular filtration rate from serum creatinine and cystatin C. N Engl J Med 367:20-29

James PA, Oparil S, Carter BL, Cushman WC, DennisonHimmelfarb C, Handler J, Lackland DT, LeFevre ML, MacKenzie TD, Ogedegbe $O$ et al (2014) 2014 evidence-based guideline for the management of high blood pressure in adults report from the panel members appointed to the Eighth Joint National Committee (JNC 8). JAMA 311:507-520
Katz S, Ford AB, Moskowitz RW, Jackson BA, Jaffe MW (1963) Studies of illness in the aged. The index of ADL: a standardized measure of biological and psychosocial function. JAMA 185:914-919

Kinsella K, He W (2009) An Aging World: 2008. International Population Reports, P95/09-1. U.S. Census Bureau, p 28 (online). Available at: http://www.census.gov/prod/ 2009pubs/p95-09-1.pdf. Accessed September 25, 2009

Knecht S, Wersching H, Lohmann H, Bruchmann M, Duning T, Dziewas R, Berger K, Ringelstein EB (2008) High-normal blood pressure is associated with poor cognitive performance. Hypertension 51:663-668

Kuo HK, Jones RN, Milberg WP, Tennstedt S, Talbot L, Morris JN, Lipsitz LA (2005) Effect of blood pressure and diabetes mellitus on cognitive and physical functions in older adults: a longitudinal analysis of the advanced cognitive training for independent and vital elderly cohort. J Am Geriatr Soc 53: 1154-1161

Lawton MP, Brody EM (1969) Assessment of older people: selfmain-training and instrumental activities of daily living. Gerontologist 9:179-186

Lopes MB, Araújo LQ, Passos MT, Nishida SK, Kirsztajn GM, Cendoroglo MS, Sesso RC (2013) Estimation of glomerular filtration rate from serum creatinine and cystatin $\mathrm{C}$ in octogenarians and nonagenarians. BMC Nephrol 14:265

Mahoney FI, Barthel DW (1965) Functional evaluation: the Barthel index. Md State Med J 14:56-61

Mancia G, Fagard R, Narkiewicz K, Redán J, Zanchetti A, Böhm M, Christiaens T, Cifkova R, De Backer G, Dominiczak A et al (2013) $2013 \mathrm{ESH} / \mathrm{ESC}$ guidelines for the management of arterial hypertension the task force for the management of arterial hypertension of the European Society of Hypertension (ESH) and of the European Society of Cardiology (ESC). J Hypertens 31:1281-1357

Matthews DR, Hosker JP, Rudenski AS, Naylor BA, Treacher DF, Turner RC (1985) Homeostasis model assessment: insulin resistance and $\beta$-cell function from fasting plasma glucose and insulin concentrations in man. Diabetologia 28:412-419

McKee PA, Castelli WP, McNamara PM, Kannel WB (1971) The natural history of congestive heart failure: the Framingham study. N Engl J Med 285:1441-1446

Molander L, Gustafson Y, Lövheim H (2010) Low blood pressure is associated with cognitive impairment in very old people. Dement Geriatr Cogn Disord 29:335-341

Mossakowska M, Broczek K, Wieczorowska-Tobis K, KlichRączka A, Jonas M, Pawlik-Pachucka E, Safranow K, Kuznicki J, Puzianowska-Kuznicka M (2014) Cognitive performance and functional status are the major factors predicting survival of centenarians in Poland. J Gerontol A Biol Sci Med Sci 69(10):1269-1275

Nilsson SE, Read S, Berg S, Johansson B, Melander A, Lindblad $\mathrm{U}$ (2007) Low systolic blood pressure is associated with impaired cognitive function in the oldest old: longitudinal observations in a population-based sample 80 years and older. Aging Clin Exp Res 19:41-47

Poortvliet RK, Blom JW, de Craen AJ, Mooijaart SP, Westendorp RG, Assendelft WJ, Gussekloo J, de Ruijter W (2013) Low blood pressure predicts increased mortality in very old age even without heart failure: the Leiden 85-plus Study. Eur J Heart Fail 15:528-533 
Qiu C, von Strauss E, Winblad B, Fratiglioni L (2004) Decline in blood pressure over time and risk of dementia: a longitudinal study from the Kungsholmen project. Stroke 35:1810-1815

Rastas S, Pirttilä T, Viramo P, Verkkoniemi A, Halonen P, Juva K, Niinistö L, Mattila K, Länsimies E, Sulkava R (2006) Association between blood pressure and survival over 9 years in a general population aged 85 and older. $\mathrm{J}$ Am Geriatr Soc 54:912-918

Richmond R, Law J, Kay-Lambkin F (2011) Higher blood pressure associated with higher cognition and functionality among centenarians in Australia. Am J Hypertens 24: 299-303

Sabayan B, Oleksik AM, Maier AB, van Buchem MA, Poortvliet RK, de Ruijter W, Gussekloo J, de Craen AJ, Westendorp RG (2012) High blood pressure and resilience to physical and cognitive decline in the oldest old: the Leiden 85-plus Study. J Am Geriatr Soc 60:2014-2019

Schaeffner ES, Ebert N, Delanaye P, Frei U, Gaedeke J, Jakob O, Kuhlmann MK, Schuchardt M, Tölle M, Ziebig R et al (2012) Two novel equations to estimate kidney function in persons aged 70 years or older. Ann Intern Med 157:471-481

Szewieczek J, Dulawa J, Gminski J, Kurek A, Legierska K, Francuz T, Włodarczyk-Sporek I, Janusz-Jenczen M, Hornik B (2011) Better cognitive and physical performance is associated with higher blood pressure in centenarians. $\mathrm{J}$ Nutr Health Aging 15:618-622

Taylor C, Tillin T, Chaturvedi N, Dewey M, Ferri CP, Hughes A, Prince M, Richards M, Shah A, Stewart R (2013) Midlife hypertensive status and cognitive function 20 years later: the Southall and Brent revisited study. J Am Geriatr Soc 61: 1489-1498

Waldstein SR, Giggey PP, Thayer JF, Zonderman AB (2005) Nonlinear relations of blood pressure to cognitive function: the Baltimore longitudinal study of aging. Hypertension 45: 374-379

Wang M, Monticone RE, Lakatta EG (2010) Arterial aging: a journey into subclinical arterial disease. Curr Opin Nephrol Hypertens 19:201-207

Zdrojewski T (2011) Prevalence and awareness of arterial hypertension in Poland and in the world. Postępy Nauk Medycznych s3:4-10

Zdrojewski T, Więcek A, Grodzicki T, Broda G, Bandosz P, Mossakowska M, Ślusarczyk P, Chudek J, Wizner B, Wyrzykowski B (2012) Rozpowszechnienie, świadomość i skuteczność leczenia nadciśnienia tętniczego u osób powyżej 65. roku życia w Polsce. In: Mossakowska M, Więcek A, Błędowski P (ed) PolSenior. Aspekty medyczne, psychologiczne, socjologiczne i ekonomiczne starzenia się ludzi w Polsce. Termedia Wydawnictwa Medyczne, Poznan, p 160 